\title{
Sampang Community Empowerment In Human Capital Theory Perspective
}

\author{
Dwi Astutiek \\ Postgraduate Student of Airlangga University \\ Majoring Human Resources Development, Indonesia \\ Mustain Mashud \\ Postgraduate Student of Airlangga University \\ Majoring Human Resources Development, Indonesia \\ Bagong Suyanto \\ Postgraduate Student of Airlangga University \\ Majoring Human Resources Development, Indonesia
}

\begin{abstract}
This research purposes are : 1. To examine how education program as human capital investment opportunity in order to improving Sampang community empowerment. 2. To find out how contestation of education between formal education and pesantren (Muslim Boarding School) influence the increasing number of illiterate people in the town. Also to find out how hegemonic factors when educational contestation took place. This research yield obtained : first, already found out, to answer the power of Sampang community required known on powerlessness hinder factors previously and will be gained solution from these hindrances. Next applying model from Richard J. Toracco's Human Capital Theory as implementation of Gery S. Breker's Human Capital Theory. Second, found the potentials of Sampang people regarding with basic potential as character human, natural potency, social structure potency, cultural potency, religion believe power potency and political potency. Furthermore these potentials can be drawn as supporting factors in realizes human capital theory perspective. Third, found a formula of model development from Richard J. Toracco's human capital. From the findings above gained as application perspective of human capital theory. Implications of this research outcome are first, in theoretical implications before human capital theory application, is necessary to known in advance empowerment inhibitor factors in region will be developed and solution of exist obstacle all at once. Then using Human Capital theory development suggested by Thomas J. Toracco as perspective of the theory. Second, practical implication are how the role of pesantren be more optimal in preparing their students. The alumnus who have bargain power position (marketable) able to answer mundane and. That is by equipping pesantren education with formal education. Using national language as an introductory language without eliminating local language. Thus will be able to raise Human Development Index (HDI) of Sampang district be better. Third, how empowerment transformation setting through pesantren, formal and nonformal education, serious and focused. Concurrently handling on involvement from various partnership elements engaged.
\end{abstract}

Keywords: community empowerment, human capital theory perspective

\section{INTRODUCTION}

Behind multiple of successes in economy development sector one of the problems that are contradictive and fundamentally there is remain people who illiterate. Illiterate in Indonesia as part of serious issues that must be handled immediately, optimally and all at once. "Absolve 
every citizen from illiterate mean that opening key for human empowerment go to long life learning people to realizes qualified welfare". (Yulaelawati dalam Kemendiknas, $2010: 3$ ).

Following the empirical data of regencies with highly illiterate number that is third rank in Indonesia is Sampang regency of 147.740 people (HDI) lowest (Kemendiknas : 2010). Impacted on Human Development Index (HDI) lowest in Indonesia. HDI become benchmark of people powerlessness in Sampang. In 2010 and 2014 HDI of Sampang positioned at 59,70 and 63,04 number movement is slow enough. People who untouched by formal education, Sampang people age 15 years old above not/or yet never go to school year 2006 and 2010 reached 235.860 and 227.837 (BPS Province of East Java). Children who drop out in elementary school age are high enough. Intelligence number of reading and writing is low. In 2010 high poverty take on position 285.4 (000) (BPS Data Province of East Java). A very concernedly condition.

Based on verification result of illiterate data of 2011, several reasons/ causes of illiterate people in Sampang cause of : go to school then drop out 13,84\%, never school cause remote from education facilitation 41,79\% ; never school because have no money 23,25\%; go to school and passed but rarely used/exercised 1,03\% ; other (lazy, disabled, culture) 20,08\%.

If studied, the development of Sampang education have central role in Pesantren. Charismatic kiai (Muslim scholar) become main figure in determine all people life aspect, included education interest, mate, lucky and many more. There is obedience value of Sampang people on bhupha', bhabhu' teacher and rato (government) kept very strong and preserved. Then learning culture in pesantren keep dominate. The problem is learning which given in pesantren different with UNESCO standard benchmark in established Human Development Index. Sampang community because studied in pesantren then did not illiterate in Madurese and Arabic, but latin literate UNESCO version. Furthermore, is it Sampang People have enough power in education context of pesantren?

This research will use benchmarks 'Theory of Human Capital' perspective, education has an effect on economic growth through economic power through increased workforce. Growth individual productivity started from individual productivity. If the individual has a high yield because gain high education, then community economic growth can be supported by it. Human capital theory assumes that education is a good investment for the individual and for society (Ismail N, 2006 : 70). To make people empowered, particularly economic, require good educational. This theory shows the importance of education factor for social and economic progress of society.

Friedman's empowerment concept, not merely economic, but also political, so that people will have a high competitive bargaining power. Empowerment paradigm intended to change completely centralized conditions to more autonomous situation by giving the opportunity to the poor class to plan and then execute development programs of their own choose. In addition, groups of poor people are also given opportunity to manage the development of both derived from governments or external parties luar (Elly M.S. \& Usman K; 2011 : 812). This means that the issue of the independence level and public access availability for Sampang. Is the real conditions of Sampang society today are quite independent and have access to education, economics and politics? 
Paulo Feire's perspective, a strict social structure conditions and suppress public access would assessed hinder people empowerment. According to him, community empowerment is an effort to encourage people to look for ways to create freedom from repressive structures (oppressive). This means that the role and importance of the Sampang social structure conditions: whether the strict, rigid and discriminative or open enough so that every citizen is free to express. Conversely, if the structure is already open, but the community remains difficult to empowered, meaning cultural factors and communities religion is problematic. In accordance with the title on this study obtained statement of the problem as follows:

\section{Statement of the Problem}

1. How does education program be an investment opportunities in human capital in order to increase community empowerment of Sampang?

2. How education contestation between formal education and boarding schools contributed to the increased number of illiterate Sampang people? Is there any hegemonic factors contestation when education takes place?

\section{THEORY OF EMPOWERMENT AND PREVIOUS STUDIES}

Empowerment, in other words can be interpreted reinforcement. Derived from the word "empower". In an Indonesian great dictionary issued by the Department of Education in 1995 stated that "empower" means having the strength and ability, it could also mean having intelligence (way) to overcome something (Ihsan Yus, 2002: 56).

According to Jim Ife in Zubaedi (2013), empowerment concept has close links two central concept, namely: the concept of "empower" and the concept of "inequality". Definition of empowerment can be explained by using four perspectives: pluralist, elitist, structuralist and post-structuralist.

a. Community empowerment in the reviewed of a pluralist perspective is a process to help disadvantaged individuals and groups communities so that they can compete more effectively with other interests. Empowerment efforts do is help them with learning, using expertise in lobbying, use of media-related political action and understand how the system is workings (the rule). Therefore, it is necessary to improve community capacities to compete fairly so that no one wins or loses. In other words, empowerment is an attempt to teach the groups or individuals how to compete within the rules (how to competitive within the rules).

b. Community empowerment in the reviewed of elitist perspective is an effort to join and influence the elites like leaders or community figures, officials, riches and others, formed an alliance with the elite, do confrontations and seek changes to the elite. This effort is done remained that public become powerless because there is a strong power and control of the elites against the media, education, political parties, public policy, bureaucracy and parliament.

c. Community empowerment in the reviewed of structuralist perspective is struggle agend that a more challenging for empowerment objectives that can be achieved whenever forms of structural inequalities are eliminated. Generally, people become powerless because of the existence of a social structure that dominates and oppresses them, either for reasons of social class, gender, race and ethnicity. In other words, empowerment is a process of liberation, structural change, fundamental and structural work to eliminate oppression. 
d. Community empowerment in the review of post-structuralist perspective is a challenging process and changes the discourse. Empowerment is more focused on intellectuality aspects rather than activity or practical action. From this perspective, empowerment is understood as an effort to develop an understanding of the development of new thinking and analysis. So the empowerment emphasizes point is on the educational aspect not an action.

Here's 'Theory of Human Capital' perspective, education has an effect on economic growth through economic power through increased workforce. Growth individual productivity started from individual productivity. If the individual has a high yield because gain high education, then community economic growth can be supported by it. Human capital theory assumes that education is a good investment for the individual and for society(Ismail N, 2006 : 70). To make people empowered, particularly economic, require good educational. This theory shows the importance of education factor for social and economic progress of society.

According to Friedman empowerment is not merely economic, but also political, so that finally people will have a high competitive bargaining power both nationally and internationally. Empowerment paradigm intended to change completely centralized conditions to more autonomous situation by giving the opportunity to the poor to plan and then execute participative development programs, groups of poor people are also given opportunity to manage the development of both derived from governments or external parties(Elly M.S. \& Usman K; 2011 : 812).

Similar statement of Paulo Feire say that community empowerment represent an efforts to push the people to seek the way of freedom from repressive structures.

Here are community empowerment processes in the United Nations (1956):

1. Getting to know the local community. Knowing the characteristic of the local community that will empowered, including characteristics differences that distinguish the village community with one another. Knowing the reciprocal relationship between the escort officer with the public.

2. Gathering of knowledge about the local community. Gather knowledge about information regarding the pattern of life of local people. Knowledge is factual information about population distribution by age, sex, occupation, education level, socio-economic status, including knowledge of values, attitudes, rituals, and custom, the type of grouping, as well as leadership factors, both formal and informal.

3. Identifying the local leaders. All efforts of community empowerment will be useless if it is not supported by the leader or local community leaders. Therefore, in the empowerment process, "the local leaders" factor must always be taken into account because it has a strong influence in the community.

4. Stimulating the community to realize that it has problems. In the communities who are bound by customs, consciously or unconsciously, people do not feel that they have a 
problem that needs to be solved. Therefore, we need a persuasive approach so that the public is aware the problems that need to be solved, and needs to be met.

5. Helping people to discuss their problem. Empowering communities implies encourage and stimulate initiatives to involve themselves in the discussion and formulate alternative solutions in an atmosphere of togetherness.

6. Helping people to identify their most pressing problem. Community guided to be able to identify the problems faced and set priorities scale that most influence on basic needs. The most crucial issues and impacted on the broader social life order, should be prioritized to be solved.

7. Fostering self-confidence. Build public confidence in dealing with various problems. Self-confidence is the main capital to build self-sufficiency.

8. Deciding on a course of action. Communities need to be empowered to establish a program that will do. The action program needs to be determined based on priorities, i.e. low, medium and high. Obviously program with higher scale priorities that need to be first implemented.

9. Recognition of strengths and resources. Empowering people means increasing people's capacity to assess the internal and external environment (strengths and resources that can be mobilized to solve their problems and needs)

10. Helping people to continue to work on solving their problems. Community empowerment is a series of planned actions aimed to change a better life in a sustainable manner to solve the problems that it faces.

11. Increasing people ability for self-help. One of the goals of community empowerment is to increase the capacity and self-help so that people can help themselves. Self-help becomes the basic values in community development efforts.

Thus, community empowerment is an entitlement to society to be able to increase the selfpower or self-ability. If the ability of the social unit as a whole increased, then all members of the public will be able to enjoy together. Giving power to the whole society will also indirectly increase the power of the donor that is the ruler (government).

\section{RESEARCH METHOD}

This study used a qualitative method with descriptive approach. Qualitative research process will involve substantial efforts, such as asking questions and procedures, collecting specific data from informants, analyzing data inductively from the specific themes to generalized themes, and interpret the meaning data. This research applies inductive style viewpoint, focusing on individual meanings, and translate the complexity of a problem. 
Process to get the informant using Snowball Approach. Snowball informant selection procedures done gradually rolling that eventually will be stopped the informant election when information obtained at the level of fixed and can be taken in accordance with the focus theme is examined. From a number of informants obtained the specified key informants as a key entrance at the start of this study. Key informants will provide more explanation and detail as people who are at the top level. Key informant is a keynote speaker who has the status of a person who has wide knowledge about his region, the habits of the population and social problems and other general nature. Key informant is commonly regarded as a prominent figure by resident region.

To simplify the research process then the researcher took Ketapang district as focus location as the only districts in the largest number of illiterate in Sampang regency of men and women aged 10 years above to 13.208 citizens in 2011 data (BPS of Sampang Regency).

\section{Community Empowerment in Sampang}

\section{DISCUSSION AND RESULTS}

Community empowerment as one of the development programs in Sampang, but only temporal and unsustainable. Empowerment program executed without strict monitoring and evaluation. Nevertheless many are involved but have not shown significant results.

Here's community development program was designed and budgeted by the Village Community Empowerment Agency are 1) Rural Community Empowerment Increase Program : a. empowerment of rural institutions and community organizations in 14 subdistrict (180 villages and 6 Subdistrict) ; b. providing education and training of technical personnel and the public ; c. procurement of rural electrical network installations in 7 districts 8 villages 8 hamlets / 800 households; d. Rural Community Empowerment Increase Program through RTM, RTHM, RTSM (Poor Household, Almost Poor Household, Very Poor Household); e. Facilitation of integrated regional development programs implementation among the villages (PWTAD) RTHM 1 districts 3 villages; f. RTHM labsite development programs in the Sreseh district. 2) Rural Economic Development Institution Program : a. facilitation of regional economic development program implementation ; b. facilitation of coastal and beach communities empowerment implementation ; c. facilitation of rural communities economy infrastructures. 3) Community Participation Improvement Program in building the village: a. Month of Mutual Cooperation Service implementation (BBGR) ; b. Rural Appropriate technology 14 subdistrict 14 villages ; c. villages and districts contest; d. Village/District Empowerment and Quality Improvement (PKPKM) in Tambelangan district ; e. Rural SelfBased Zone Development (PDM-BKP) in Camplong district. 4) Women Role Improvement Program in the Rural area (development of PKK).

The activities organization in the community development fields includes community resistance, social, cultural, economic.

\section{ANALYSIS: COMMUNITY ECONOMIES CONDITION OF SAMPANG}

If viewed of the livelihoods of the Ketapang population majority is farming and fisherman, then it could be expected earnings. Rice farming by using rainfed paddy systems, then for a year only one harvest the rest is used for cultivating. As for fishing following the wind direction could sail when it's time to fishing in the sea. Due to the irregular income and can not meeting 
for his family needs on average husbands or young men there are even some women are also in the end decided to go wander and even become as Overseas Indonesian Workers (TKI) to earn more great income. The places to wander about chosen were Borneo, Malaysia and Saudi Arabia.

Due to limited the capabilities of knowledge and education only at Public Islamic Elementary School (Madrasah Ibtidaiyah) even never school or drop out at the primary education, then the job is obtained in the overseas around for manual workers like construction workers or domestic helpers. With meeting many family members automatically their needs were many too. So their revenue still not sufficient but at least can help family needs. Because of the many men who wander away, then remain population in the Ketapang district majority of women and elderly men and children.

Because of the economic situation, then there are still many residents of Ketapang categorized poor and poor vulnerable.

ANALYSIS: SOCIAL STRUCTURE CONTEXT AND THE EFFECT OF EMPOWERMENT LEVEL Value hierarchy of obedience that upheld is "bupha", "babhu", "guru", "Rato" (mother and father, teacher/kiai [religious leaders] and the king [formal leader]). System shows respect and appreciation to the biological parents, teachers/ Kiai as a spiritual parent and formal leaders. Apply in a structured and very strong as Social and Political Systems in the Madura community of Sampang.

Mother or parents are the first person to be respected and adhered to in the structure of the Madurese. All things related to the child what parents say and children must be obedient including determining educational affairs. When parents have difficulties and unable to find solutions to the problem himself and his family then nothing else will come to the kiai who are considered as teachers who are able to give advice and suggestions for the future of the world and afterlife. In other words, the end point of the life choice decision of Madurese world and hereafter are in the hands of teachers/kiai. So it will be a great impact on the final decision factor in choosing where and how their children will go to school or study.

In this context, how and to what extent the understanding of teachers/ kiai in addressing the problems that occur with each congregation or community. Providing solutions or advice according to the needs of the times remain in the corridor are not out of line with religion dogma?

Social structure that is becoming a very strong binding factor, even stiff and indirectly very stressful for the sustainability of public life of Sampang. How not all of what the teacher / kiai are about world and hereafter affairs. Obedience values highly on the teacher/kiai in all matters of the world and afterlife could be a boomerang for the congregation/ Madura community whenever human capital of the teacher/kiai is not equipped with the ability/ competence as required by the community. As existing in relation to the choice to get an education in school or in pesantren. At last allurement or motivation behind it is unnoticed has been pressed to indirectly have occurred hegemony in the social structure of the Ketapang society. 
In conditions of social structure in Sampang which according to Paulo Feire perspective, the condition of social structure are strict and suppress public access would inhibiting community empowerment. According to him, community empowerment is an effort to encourage people to look for ways to create freedom from repressive structures. So hopefully there will be a solution of motivation or a non-binding bargain to convey what the conditions in boarding schools to give encouragement to schools in formal education or even a boarding school where possible in the attempts to establish a formal education will automatically follow the curriculum set by the government. So at the end of graduation will get a diploma as proof of survival in the future. Of course, the learning process in formal education will use the national language.

These conditions internationally will be able to help raise the Human Development Index (HDI) of Sampang. During the constraints due to the low HDI in Madura because UNESCO benchmarks used different from the situation and the reality in Madura. UNESCO uses international/national language while Madurese in its education almost of the people who study in boarding schools use Madurese or Arabic language. So they are literate in Arabic but Latin illiterate.

\section{ANALYSIS: THE SOCIAL CONTEXT, CULTURE, AND RELIGION BETWEEN SUPPORT AND BARRIER ("CULTURAL TRAP" AND "RELIGION TRAP")}

Culture can bring people to the highest glorious level. But culture also bring us in a retardation position. How about the culture in Madura?

Learning culture in Madura society are langgar/mushollah/mosques and boarding schools is done for generations by generations. Values that instilled in the offspring is the value of obedience to the teacher/kiai to ngalah barokah (hoping to get blessing knowledge of the reading Al Quran from a teacher/kiai).

Learning culture in langgar / mushollah/ mosques and boarding schools is a good habit and have high value, but also a weak point when learning is not supported by formal educational facilities that needed by the society today. Learning contexts in langgar/ mushollah/mosque to learn and reading Al Qur'an (sorogan), nglalar Al Qur'an. In boarding school complete with studying the Salaf books. The language of instruction using the mother tongue (Madurese) using Arabic writing books speak pego Java-Madura. While benchmarks for rising the value of the Human Development Index (HDI) of Sampang society required international language use of minimal national language to read and write. So HDI of Sampang regency including low category because its people are latin illiterate but they are literate Arab Pego Madura. So that it becomes an obstacle for people to raise the empowerment value of Sampang self. Thus condition show that the "cultural trap" issues, has long been rooted and is still occur today.

The other hand, religion into its own power on the way of life of every human being. But a constraint whenever there is a wrong understanding on the meaning of a value. Hadistt history of Tirmidzi about the suggestion to marry, which reads:

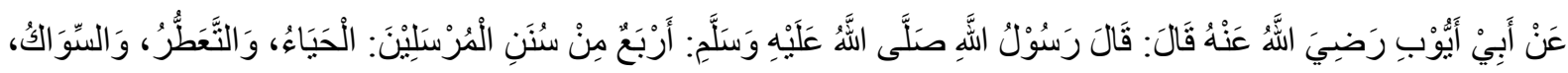

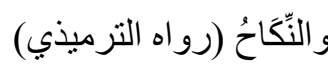


From Abu Ayyub Radliyallahu anhu said Rasululallah sallahu alaihi wa sallam saying that : "There were four cases which includes the Sunnah of the Apostles: shame, wear fragrances, tooth brush, and get married." (HR. Tirmidzi)

The following Hadith History of Tabarani:

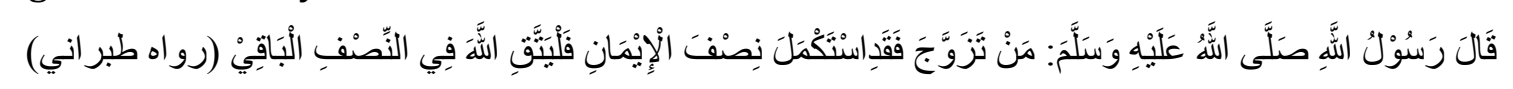

The Prophet Shallahu Alaihi wa sallam saying: "Whoever married (get married), then he half enhance the faith, because it let him devoted to God in the other half." (HR. Thabrani)

According to Sampang society both the hadith is interpreted as a necessity to have an impact on the technical implementation of the rush. Proven majority of children in Sampang married by her/his parents at a young age / early age if in view of the Indonesia regulations. Namely Acts No. 1 of article 7 paragraph 1 of 1974 concerning marriage, married age limit for women is 16 years and men 19 years. While the Sampang marry off their children on average at the age of 12-13 years after graduating Madratsah Ibtidaiyah even many who do not finish the school. If there is no mate for the child then advised to keep studying in boarding school while waiting for a mate. With great anticipation and a sense of high concern "takok not paju lakeh" (anxious not sold).

Understanding such a problem for the sustainability of the fate of future generations. Mistake understanding supported by strong culture that happened:

1. Unpreparedness child in social emotional when building a household

2. Maturity level has not been nurtured, effect on the level of the child's independence.

3. Unpreparedness physically, because the prone position gave birth age.

This treatment has been entrenched in the Madura community and can be said to have deprived childhood in play and learning for the empower. It is the impact of the understanding religious and cultural issues that should receive special attention from religious leaders, community leaders and government.

\section{ANALYSIS: POLITICAL CONTEXT AND COMMUNITY EMPOWERMENT}

The education management is part of efforts to empower community. The problem is the amount that must be empowered with budget allocation is not balanced, must go through the process and takes quite a long time. Until now the number of illiterate people in underserved through eradication of illiteracy program and studying package program is still quite a lot. It is still a duty for the Sampang government. The courage to take a stand in making policies is required of a leader. Priority programs needs to be done, just do poverty in by disdain.

Choosing a good leader is a must. But the existing problems give an illustration, the public assumes that the direct leadership election in Sampang is a regular event, only benefit for certain parties. Even emerging public antipathy towards politics, as the following statement by the 'F':

"just like before, one who elected is one who cheating, so why get involved, that so in vain..." (Inf. 6)

These conditions have an impact on community non-involvement in the development and away from political knowledge. Finally community powerlessness ensued. 
In Friedman's statement, empowerment is not merely economic but also political, so that people have a competitive bargaining power and highly. Empowerment paradigm intented to change the conditions that completely centralized to more autonomous by giving the opportunity to the poor class to plan and then execute development programs of their own choosing. In addition, groups of poor people are also given a chance to manage the development of both derived from governments or external parties. This means that the issue of the independence level and access availability to the Sampang community.

The above analysis, the real conditions of Sampang society today there are issues of powerlessness occur. First, access availability factor to education is limited from budget allocation. Meaning there is allocation imbalance between the budget allocation by the number of citizens who are illiterate and the people who DO or never school. Second, the access availability to participate in choosing the leader was deprived or up the spout. So, there is no chance to be independent and empowered.

\section{ANALYSIS: CONTESTATION OF FORMAL EDUCATION AND BOARDING SCHOOLS}

Low HDI as the impacts of the fifteen years back, still many latin illiterate people, means it is still not be completed handling. The following analysis in the contestation arena of education programs in Ketapang:

\section{a. Contestation of formal educational and schools institutions.}

When the existence of formal educational institutions and facilities in Ketapang is very limited. Education services still did not meet the quality standards of education service. So current information on the number of accredited educational institutions both very lack. The established formal education institutions still rely on government support both public and private, BOS funds began to increase the number of formal educational institutions in Ketapang. However, the existence and formal educational opportunities outside of the boarding school is not as strong as formal education institutions like boarding school environment. Clearly existence is supported by the basic potential of Ketapang people who have confidence in the figure of a charismatic religious scholars and mbarokai (give blessing). Besides the establishment of boarding schools because of the spirit of religious scholars in teaching and developing Islamic education. Since ancient times until now, before any BOS funds come the number of boarding schools to keep raise up. With BOS so the boarding program services added like education formal. The situation was strongly supported by the following points:

Opportunity program, the local economy is very low and the allocation of government funds is quite limited. Until now there is movement in the development of educational programs in Ketapang but nothing too significant to the needs of the population that should schooling. Currently there is an understanding that higher education is only for high level children such as kiai, Rato/ officials. Seen that opportunity was not optimal program and uneven. On the contrary, chance at the boarding school education programs dominate since the founding of boarding schools because of the concern of the scholars or kiai. Then the existence of boarding schools more able to accommodate the children who want to learn. This is supported by the belief of obedience to parents and adherence to the teacher/kiai. Motivation is provided by scholars on students or congregation like this: "God's studying in boarding schools, other than that the Al Quran is the deliverance in hereafter". The parents advice on their children: "Because you are not descendants of kiai then learn in boarding schools - get a blessing". 
Infrastructure Access, due to the limited education number also limited access of the existing road infrastructure. It is the measure of the distance of the school, and road conditions are steep and winding and there is no asphalt road. Electricity aspek and telecommunications also unevenly distributed, limited and does not economical affordable. Distance so far can be the one factor that inhibiting people who intended to studying in formal schools. This condition is indirectly supporting the community thought that school is not very important and does not have an impact on household income. Because become a fishermen did not need school. Finally people decided not go to school. Enough to learn the Al Quran in nearby musholla/surau/ mosque. Further suggested by the teacher/kiai go to boarding schools where a place teachers/ kiai first to study. When in the boarding school is not equipped with formal education. Education learning system model using sorogan. While instruction language using Madurese. The books uses Arabic pego Java-Madura writing. This condition has an impact on increasing the number of latin illiterate.

Access to Information, the current educational facilities is limited. There is understanding that higher education is only for the child from the upper class such as teacher/clerics and Rato/officials. It have an impact on the education information was not obtained because only specified groups. Next to the increasing number of educational institutions increases, but the strength understanding of education in boarding schools remains more even though there are no formal educational within them. So information and motivation of the kiai become decisive in deciding the attitude of students or congregation to get education. In some recitals event, both in and outside the boarding a kiai always convey the importance of preparing bandana akherat (hereafter provision) by studying the Al Quran at the boarding school. This motivation conveyed started earlier times until now. The difference is if the boarding school there is no formal school service. Today is many boarding schools have additional services such as formal education.

\section{b. Ongoing hegemony factor}

Analyzing the previous article, it is not felt to have occurred ongoing hegemonic factor. The suggestion of parents to their children can not be separated from the advice that was brought by a kiai. Then a students or parents of students to make decisions based on the advice of the kiai. As an example of information 'B' motivation of parents on their children following:

'Because you are not descendants scholar then learn in boarding school, in order to get blessing of kiai .... "(Inf. 2)

Further information submitted by the 'B A', on the advice of a teacher / kyai currently underway following study:

"... .ngaji (learning) at the school here only requires knowledge of God, did not think an angel when asked in barzah world about general knowledge, most are in question about sholat or reading Al Quran"... " (inf.2.1)

There is even a statement delivered 'B' as following:

"... .if you not go to school here I'm not going to read talqin" (talqin readings for the dead) ...." (Inf. 2)

Advice and motivation of the kiai to his congregation very adhered to, so that the majority of Ketapang districts in fifteen years back study in boarding schools. Without learning to formal 
education institutions, which in reality is very needed by citizens to learn in formal education to be get power. With studying formal education people can be exist independently and have have a bargaining position in the arena of the regional development. However it was not done, because the citizens adhered the value of tawadlu from teacher / kiai. All advices obeyed because the hope of getting a blessing obedient to the teacher/ kiai. This issue may not be realized by the community to the impact of what happens to the future. Community active role involvement in the development and even the self existence of people is ultimately less considered. It proven when a couple of times of chief election up to the presidential election less involved in determining the choice of selecting their leaders. Election moment of the leader but the people do not involved. And people have no power to do rebellion, silent, desperate and defenselessly. So in the end and until this moment Sampang regency by UNESCO was declared as one of the most illiterate people districts in Indonesia.

Implicitly and explicitly among several sentence found tight and pressing elements, the following two examples of sentences that researchers take:

"... .ngaji (learning) at the school here only requires knowledge of God, did not think an angel when asked in barzah world about general knowledge, most are in question about sholat or reading Al Quran"... "(inf.2.1)

And also,

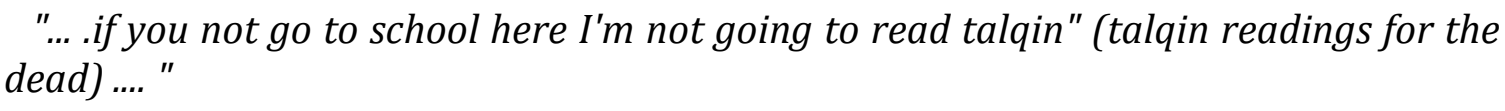

Two sentences above implies a tight and pressed the public in using access rights as human beings who want to learn to get powered. Studying where it wants and will. Even the sentence can seem a threat if understood rigidly with no regard to the proximity between the kiai and his students. As Paulo Feire perspective the strict conditions of social structure and suppress public access would assessed hinder community empowerment. According to him, community empowerment is an effort to encourage people to look for ways to create freedom of repressive structures (oppressive).

\section{c. Participative and marketable of empowerment paradigm}

The previous description has been describing their limited access. According to Friedman, this does not merely economic but politically not competent and not competitive because it has no bargaining power. Paradigm empowerment intended to change the conditions that completely centralized to more autonomous situation manner by provide opportunities for the poor to plan and then implement participatory development programs. Communities were given the opportunity to manage development programs from both government and externals. It means a problem of the independence level not having access to education, access to participatory did not gained. In fact these communities need access to be powered, so that it can overcome the problem himself and his people. In the end, community in Ketapang district until this moment can be said is still not able to answer the needs of the market.

From the description that there is movement and development of education in Ketapang impressed no contestation of the struggle for their education interests. There is seem a space between the interests kiai and the government. Recognized or no there is contribution and kiai 
in building this country through education in boarding schools due to a lack of role of the government. Boarding school to take part in order to fill the empty opportunities and gaps occurred. Although what have done not too elegant so looks there is hegemony happened. The problem now is how the role of schools to be more optimal in preparing its students? Graduates who have a bargaining position (marketable) were able to respond to market needs the world and the hereafter.

\section{ANALYSIS: HUMAN CAPITAL THEORY PERSPECTIVE ON COMMUNITY EMPOWERMENT}

Human capital is a part of human resources at the level of adding value where they can not be separated from its origin as Human Resources, which is equipped with the added value. According Fitzens, (2000) definition of human capital can be described as a combination of the following factors:

a. The characteristics of a person he was born into work, intelligence, energy, generally positive attitude, reliability, and commitment.

b. One's ability to learn, talent, imagination, creativity, and what is often referred to as street smart (sense of intelligence).

c. The motivation for someone to share information and knowledge, team spirit and goal orientation.

At this level, Ketapang people has potential as a Human Resource base. Among base potential such was bharenteng (very active), firm, hard, bhajeng (diligent), tenacious, cakang (agility), parèkas (resourceful), tangginas (fast-acting), excited, abhabbha '(works by exerting all abilities), abhantèng tolang (drudge), acèko (actively working with hand gestures that busy), acèmeng (busy working up can not stay silent), apokpak (busy working two or more jobs at once), asèpsap (working while running around), ce 'ngadhebbha da' lalakonna (very earnestly carry out the work), abhalunteng (working hard). However the existing potential is not functioning optimally and may even be buried. This condition occurs because there is an inhibiting factor causing powerlessness in addressing the various aspects of the current development challenges.

One way to addresing the condition is to find the limiting factor of powerlessness that further touch of education to do. The importance of education has been emphasized since ancient times by the experts. Education is often regarded as the most important determinant of a person's social and economic success.

Human capital refers to the knowledge and expertise accumulated through education and training. Emphasizing the importance of the social and economic impacts of the theory of human capital. Becker (1993) cites economic dictum of Alfred Marshall, "the most valuable of all capital is that invested in human beings".

Education has the objective of preparing a more productive worker. Approach humanism requires the educational process as a total process to develop the whole person. The dual role of education needs to be emphasized and implemented. These roles are:

1. Education serves to foster humanity (human being). This means that education is ultimately intended to develop the whole person, including the preparation of human beings as members of society, a good citizen and a sense of unity (cohesiveness). 
2. Education as a human resources function is to develop the ability to enter a new era as a competitive life and employability (H. A. R. Tilaar, 2000).

On the condition of the Ketapang people: if people have educated human capital it has the independence and value of fresh competitive social, economic and political participation that will provide more value added acceleration of the development process in this country. Just like what was described by Gery S. Becker in Figure 1 below:

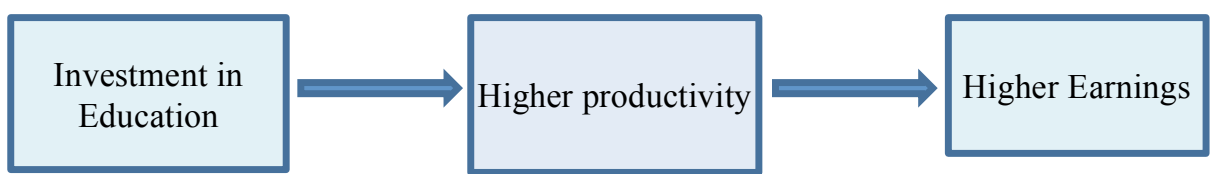

(a)

(b)

(c)

Figure 1 The Human Capital Approach

Figure 1 where A (investment in human capital) leads to B (higher productivity of workers) which in turn causes $C$ (higher profits) or in other words the public contributes to giving its participation in the development process in this country. Because if the high level of investment in human capital, the tendency of opportunities for people to participate in development.

Furthermore, by Richard J. Torraco in his RA Swanson \& EF Holton III presented a theoretical model of the Human Capital:

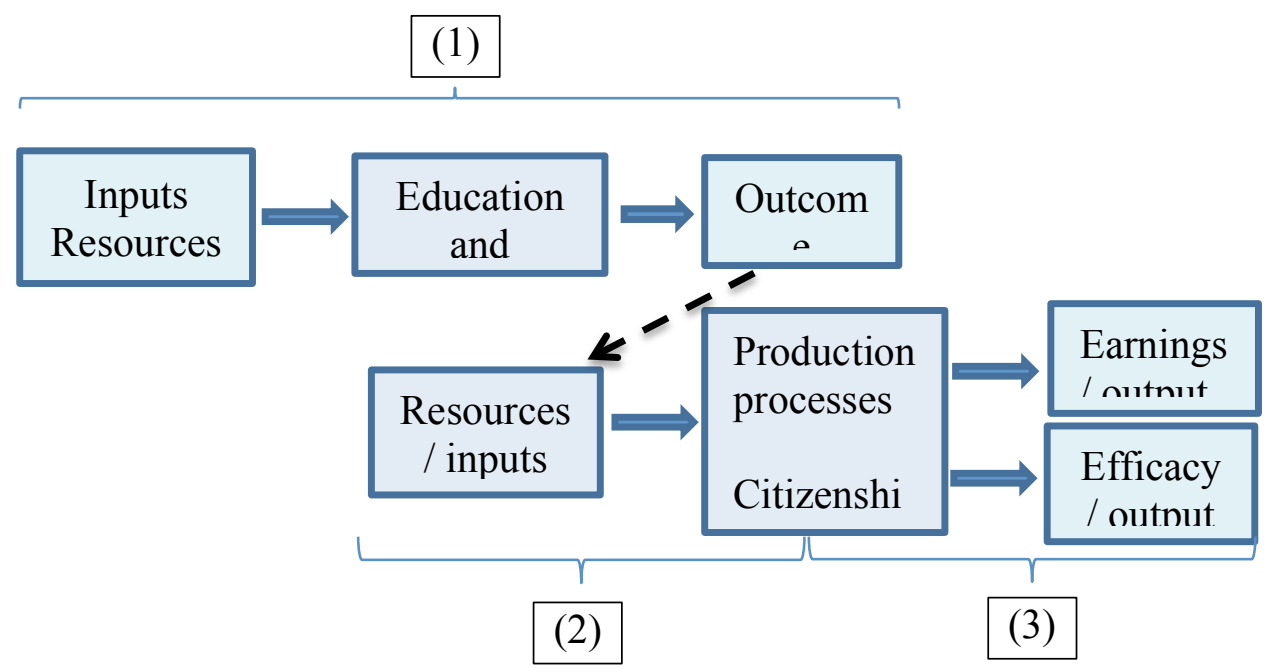

Figure 2 A Model of Human Capital Theory

Model of Human Capital Theory in figure 2 presents the key link in the theory of human capital and the assumptions underlying this relationship. Key relationships and assumptions of the theory of human capital represented in Figure 2 by the numbers in brackets 1, 2, and 3. Based on the theory of the system, the relationships in Figure 2 is a process model, each consisting of input, process and output.

a. Relations 1 represents the concept of the production function is applied to education and training. This relationship demonstrates the potential of education as a means to encourage learning and human resource development. Relation 1 is a process model 
that shows that the input / resources for education and training (for example, investment in schools, instructors, learning materials, etc.) should produce learning outcomes. Perhaps as people participating in education and training, they are involved in learning to acquire knowledge and skills. The key assumptions underlying this relationship is that investment in education and training, in fact, "did not lead to increased learning. Relation 1 includes human capital variables was assessed using a cost-effectiveness analysis.

b. Relations 2 is a human capital relationship between learning and increased productivity. This relationship shows the potential contribution of education and learning to improve productivity. Model processes in relation 2 shows that increasing the learning should result in increased productivity. Perhaps as people gain more knowledge and skills, they apply these skills in their work and thus increase productivity. The key assumptions underlying this relationship is that the increase in learning, in fact, did not result in increased productivity.

c. Relations 3 is the linking between the human capital productivity, increased wages and business income, and among the growing process of citizenship and increasing social efficacy. Perhaps as increased productivity, business income is generated which results in higher wages for employees and higher revenue for the business. Similarly, as the process of citizenship education is affected by the upgrade (for example, community involvement, voting, socially responsible actions), social capacity would be expected to increase (eg, social justice and opportunity, enhancing the environment). The key assumptions underlying this relationship is that the increase in productivity, in fact, did not result in increased wages for individuals and for business income. An assumption of equal importance of human capital theory, represented by Relation 3 is that the increase in the citizenship process is influenced by education, in fact, also deepens the social efficacy.

d. The whole series of human capital represented in Figure 2 (i.e, all of the relationships brackets as a single continuum) were assessed using analysis of return-on-investment or cost-benefit analysis.

Back to the empowerment issues in Sampang is deemed not optimal success, it was found there are several inhibiting factors. In this case is necessary to analyze the sensitivity of the inhibiting factors and seriousness in seeking a solution to the exist obstacles. The Becker concept on human capital approach when applied to people in Sampang will be successful when knowing the inhibiting factor. It is expected to facilitate and simplify the process of empowerment.

The following researchers offers developed a theoretical model of human capital by incorporating the relationship inhibiting factors and solutions for empowerment in a model of human capital theory of Richard J Torraco, namely in the following figure : 


\section{(1)}

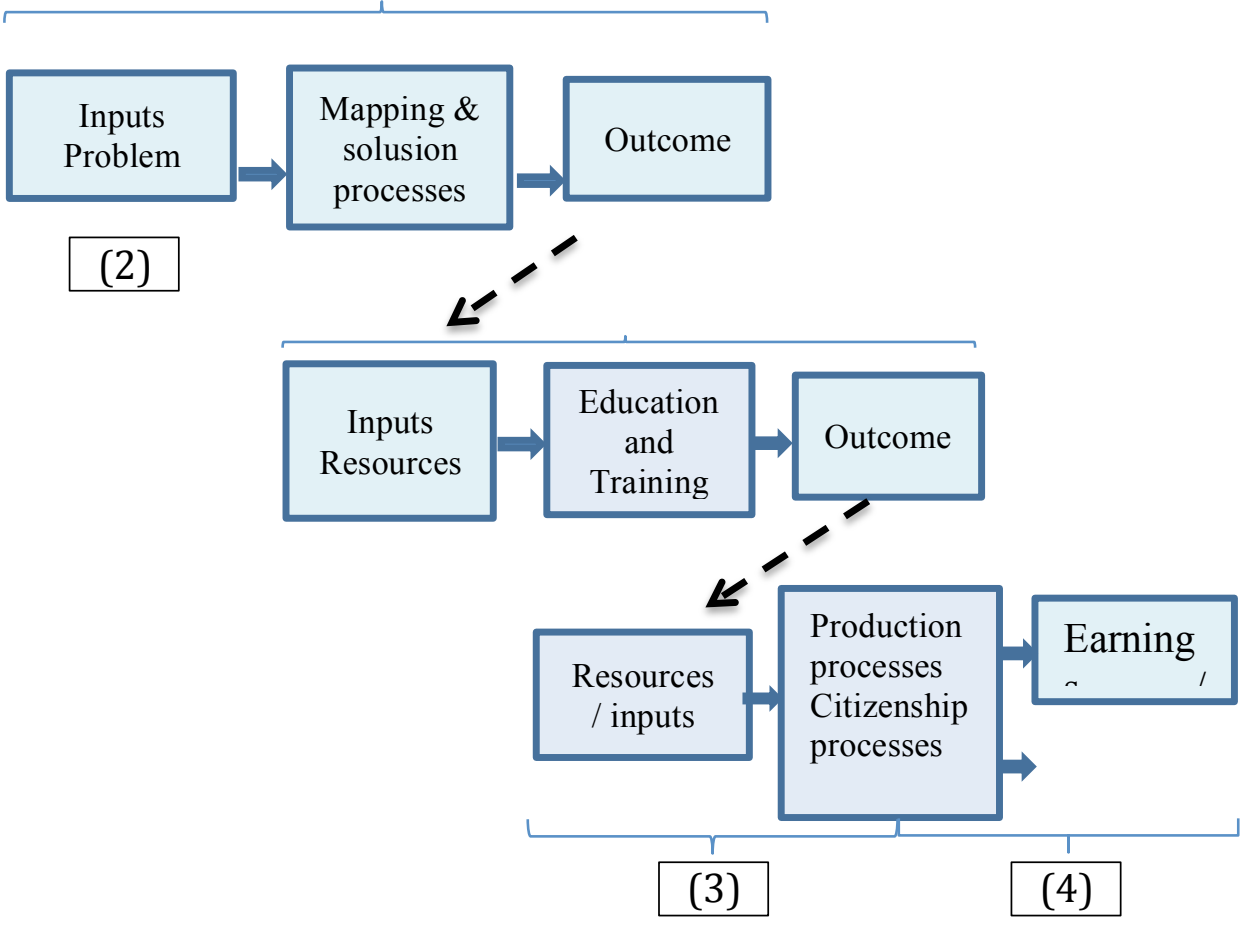

Figure 3. A Model of Human Capital Theory Development

Figure 3 presents the key link in the theory of human capital and the assumptions underlying this relationship. The development of models of human capital theory by Richard J Torraco reflected on the relationship 1. This relationship represents the identification of a problem as input problem which is a follow beginning of mapping and projection solutions to overcome barriers to empowerment, and had to be able to break down the existing problems. Further into the entrance to the relationship to the 2, 3 and 4 as described by Richard J Torraco. The key assumptions underlying this relationship is the input problem presented was not able to break down the barriers that exist.

The evidence suggests, inhibiting factor proved their powerlessness in Sampang proven there are social trap structure, cultural trap, trap religion, political trap and the absence of some access to independence and community participation in development. Inhibiting factors This powerlessness that distort the function of social capital, financial capital, natural capital, cultural capital, the religious capital, political capital, capital access/infrastructure into a potential that is not functioning in the proper context. Inhibiting factors make people powerlessness away from the value of self-reliance and active participation in national development arena.

There are aspects that intersect one another, thus becoming inhibiting factors in the process of empowerment.

Psacharopoulos and Woodhall (1997) Human resources are the main basis of the state-nation wealth. Capital and natural resources are passive factors of production, the human is an active institution that accumulating capital, exploit natural resources, build social, economic and 
organization political, and carry forward the development national (in Olaniyan. DA and Okemakinde. T: 2008).

\section{CONCLUSION}

In the study comprises of : one, it has been found for the application of the theory of Human Capital of Gery S. Absorber is neccesary to knowing about inhibiting factor of powerlessness in advance and will be the solution of these barriers. The barriers found are constraints social structure, culture, infrastructure, politics and education to the ongoing contestation of hegemony. The social structure phenomenon of Ketapang society happen also hegemonic symptoms lasting by prominent figure and also a tojing (Tokong bajing) or local thugs. The leave some aspects of the problem: incorrect understanding on the meaning of religious orders, powerlessness in accessing education and powerlessness in political participation. Furthermore, the new applying the model of the theory of Human Capital of Richard J Toracco as the theory of Gery S Absorber's Human Capital application. Two, was found with respect to the potential of the community Sampang, basic potential as a human character, the natural potential, the potential of social structure, cultural potential, the potential power of belief in the potential of religion and politics. Furthermore, this potential can be drawn into the advocates factor in realizing the perspective of human capital theory. Three, discovered the formula of model development of human capital theory Richard J Toracco. The findings as an application from the perspective of human capital theory.

\section{IMPLICATIONS}

Implications of these results are first, in theoretical implication prior to the application of the theory of human capital, need to know first inhibiting factor of empowerment in the area to be developed and at the same time the solution of the barriers. Furthermore, the new use of the theory of the development of Human Capital at Thomas J Toracco as perspective of theory. Second, practical implications is how the role of boarding schools to be more optimal in preparing his students. Graduates who have a bargaining position (marketable) were able to respond to market needs the world and the hereafter. Namely by completing boarding school education with formal education. Using the national language as the language of instruction without eliminating the local language. So it will be able to raise the Human Development Index (HDI) of Sampang be better. Third, how transformasi empowerment setting through schools, formal and non formal education took place in earnest, serious and focused. simultaneous mandagement with inclusion of various elements of partnership be engaged.

\section{REFERENCES}

Book :

Badan Perencanaan Pembangunan Daerah Kabupaten Sampang Tahun 2015, Peraturan Bupati Sampang No. 25 tahun 2015 tentang Rencana Kerja Pembangunan Daerah (RKPD) Kabupaten Sampang Tahun 2016

Becker, G.S. 1992. Human Capital : A Theoritical and Empirical Analysis, with Special Reference to Education. The University of Chicago Press. Chicago.

Cohn Elchanan, 1979. The Economic of Education, Ballinger Publishing Company, Cambridge, Massachusetts A Subsidiary of Harper \& Row, Publishers, Inc America

Coleman S James, 2010, Dasar-Dasar Teori Sosial Foundations Of Social Theory, Bandung, The Belknap Press of Harvard University Press

Creswell, J.W., 2010, Research Design Pendekatan Kualitatif, Kuantitatif, dan Mixed., Yogyakarta, Edisi Ketiga, cet. I, Pustaka Pelajar

Data BPS Jawa Timur, 2011, Data Makro Sosial dan Ekonomi Jawa Timur tahun 2006 - 2010 
Data BPS Jawa Timur, 2011, Hasil Susenas 2010 Provinsi Jawa Timur

Data BPS Kabupaten Sampang, Sampang Dalam Angka 2011

Creswell, J.W, 2009, Research Design : Qualitative, Quantitative, and Mixed Methods Approaches, Third ed., Thousand Oaks, CA : Sage

H. A. R Tilaar, 2000, Pendidikan Abad ke-21 Menunjang Knowlegde-Based Economy Analisis CSIS. Tahun XXIX/2000, No.3, Jakarta.

Kemendiknas, 2010, Pendidikan Kraksaraan Pemberdayaan Masyarakat Marginal, Jakarta.

Latief A Wiyata, 2013, Mencari Madura, Jakarta, Bidik-Phronesis Publishing

Nawawi, Ismail, 2009. Pembangunan dan Problema Masyarakat, Kajian Konsep, Model, Teori dari Aspek Ekonomi dan Sosiologi, Surabaya, CV Putra Media Nusantara

Setiadi M Elly \& Kolip Usman , 2011, Pengantar Sosiologi, Jakarta, Kencana Prenada Media Group

Swanson A Richard \& Holton III F Elwood, 2008, Foundations of Human Resource Development, Sanfransisco, Berrett Koehler Publisher

Yus, Ihsan, 2002. Dari Gerakan Pembelaan Menuju Pemberdayaan (Peran LSM Riau Mengembangkan Kapasitas Masyarakat, Pekanbaru Riau, Bahasa Press.

Undang-Undang nomor 1 pasal 7 ayat 1 tahun 1974 tentang perkawinan

\section{Jurnal}

Olaniyan. DA \& Okemankinde. T, 2008. Human Capital Theory : Implikasi untuk Pengembangan Pendidikan Eropa Jurnal Penelitian Ilmiah. ISSN 1450-216X Vol.24 No.2 (2008), pp.157-162 @ EuroJournals Publishing, Inc http://www.eurojournals.com/ejsr.htm

UNESCO, Oktober 2005. Literacy Initiative for Empowerment (LIFE), Devisi Pendidikan Dasar-Sektor Pendidikan. https : //almanhaj.or.id/ 